\title{
The impact of abdominal and laparoscopic hysterectomies on women's sexuality and psychological condition
}

\section{Abdominal ve laparoskopik histerektomilerin kadın cinselliği ve psikolojik durumuna etkileri}

\author{
Meryem Kürek Eken'1, Gülşah İlhan², Osman Temizkan³, Evrim Erbek Çelik ${ }^{4}$, Dilşad Herkiloğlư ${ }^{5}$, \\ Ateş Karateke 5 \\ 1 Adnan Menderes University Faculty of Medicine, Department Obstetrics and Gynecology, Aydın, Turkey \\ 2 Süleymaniye Training and Research Hospital, Clinic of Obstetrics and Gynecology, İstanbul, Turkey \\ 3 Şişli Hamidiye Etfal Training and Research Hospital, Clinic of Obstetrics and Gynecology, İstanbul, Turkey \\ 4Zeynep Kamil Training and Research Hospital, Clinic of Psychiatry, İstanbul, Turkey \\ 5Zeynep Kamil Training and Research Hospital, Clinic of Obstetrics and Gynecology, İstanbul, Turkey
}

\begin{abstract}
Objective: To investigate whether there were any differences in the quality of life, sexual function, and self-esteem of patients who underwent total laparoscopic hysterectomy (TLH) $(n=42)$ and total abdominal hysterectomy (TAH) $(n=42)$.

Materials and Methods: All premenopausal patients who underwent TLH or TAH because of benign uterine disorders were enrolled. The sexual function and quality of life status were assessed preoperatively and 6 months postoperatively using three standardized validated questionnaires: the Arizona Sexual Experiences Scale (ASEX), the Symptom Checklist-90-Revised (SCL-90-R), and the Rosenberg Self-Esteem Scale (RSES).

Results: Preoperative ASEX, SCL-90-R and RSES scores were not different among the hysterectomy subgroups. The postoperative SCL-90-R scores were also not different among the hysterectomy subgroups. The postoperative RSES scores were significantly lower $(p<0.05)$ than the preoperative scores for all procedures (indicating improved self-esteem) but did not differ among the groups. The postoperative ASEX scores were significantly decreased (p<0.01) as compared with the preoperative scores (indicating improved sexual function). When the average score of each item of the ASEX score was compared in both groups, significant differences were observed in sexual drive and arousal in the laparoscopy group ( $<<0.01)$.

Conclusion: Women undergoing TLH for benign uterine disease may have better outcomes related to certain sexual function parameters than women undergoing TAH.

Keywords: Total abdominal hysterectomy, total laparoscopic hysterectomy, sexual function, self-esteem, quality of life

Öz

Amaç: Benign nedenler ile total laparoskopik histerektomi (TLH) veya total abdominal histerektomi (TAH) operasyonu olan hastalarda ameliyat şeklinin hastanın yaşam kalitesi, cinsel işlev ve benlik saygısına olan etkisini araştırmayı amaçladık.

Gereç ve Yöntemler: Benign uterin hastalık endikasyonuyla TLH ( $n=42)$ veya TAH $(n=42)$ yapılan premenopozal cinsel olarak aktif hastalar çalışmaya dahil edildi. Cinsel fonksiyon ve yaşam kalitesi preoperatif ve postoperatif 6. ay da standardize ve valide edilmiş anketler ile değerlendirildi.

Cinsel fonksiyonlar Arizona Cinsel Yaşam Skalası (ASEX) ile Revize Edilmiş Psikolojik Belirti Taraması-90 (SCL-90-R) formu ile benlik saygısı ise Rosenberg Benlik Saygı Ölçeği Skalası (RSES) kullanılarak değerlendirildi.

Bulgular: Preoperatif ASEX, SCL-90-R ve RSES skorlarında histerektomi grupları arasında fark izlenmedi (p>0,05). Postoperatif 6. ayda bakılan SCL-90-R puanları da histerektomi alt grupları arasında farklı değildi ( $>0,05)$. Postoperatif RSES puanları tüm prosedürler için preoperatif puanlardan anlamlı olarak daha düşük bulundu (benlik saygısında artma) $(\mathrm{p}<0,05)$, ancak gruplar arasında anlamlı farklılık izlenmedi $(\mathrm{p}>0,05)$.

Postoperatif 6. ayda bakılan ASEX puanları preoperatif puanları ile karşılaştırıldığında anlamlı derecede azalmıştır ( $<<0,01)$ (cinsel fonksiyonlarda iyileşme). Her iki grubun ASEX alt grup skorları karşılaştırıldığında laparoskopi grubunda cinsel dürtü ve uyarılma skorlarında anlamlı farklılık gözlenmiştir (p<0,01). Sonuç: Benign endikasyonla TLH olan kadınların TAH olan kadınlara göre daha iyi cinsel fonksiyon sonuçları gösterebilir.

Anahtar Kelimeler: Total abdominal histerektomi, total laparoskopik histerektomi, cinsel fonksiyon, benlik saygısı, yaşam kalitesi
\end{abstract}

Address for Correspondence/Yazıșma Adresi: Gülşah İlhan, MD,

Süleymaniye Training and Research Hospital, Clinic of Obstetrics and Gynecology, İstanbul, Turkey

Phone: +90 5327019824 E-mail: gulsah.keskin.84@hotmail.com

Received/Geliș Tarihi: 03.08.2016 Accepted/Kabul Tarihi: 06.11.2016

${ }^{\oplus}$ Copyright 2016 by Turkish Society of Obstetrics and Gynecology

Turkish Journal of Obstetrics and Gynecology published by Galenos Yayınevi. 


\section{Introduction}

Hysterectomy is one of the most common gynecologic operations performed in developed countries and is usually performed for benign disorders $(1,2)$.

Sexual function and the quality of life have been the focus of many recent studies. Investigation of the effects of hysterectomy performed for benign indications on sexual function and postoperative quality of life have led to varied results. Hysterectomy may cause sexual dysfunction in the postoperative period $(3,4)$. On the other hand, abnormal uterine bleeding, endometriosis, and adnexal or uterine pathologies can lead to sexual problems, and pain reduce quality of life ${ }^{(5)}$. The rapid progress made in laparoscopic surgery over the past 20 years has been a crucial development in gynecologic surgery and plays a role in the determination of treatment ${ }^{(6)}$. The most significant benefits of laparoscopic surgery include decreased blood loss, lower risk of surgical site infections, shorter hospital stays, and rapid return to normal daily activities in laparoscopy compared with laparotomy $(7)$. However, studies investigating postoperative psychological effects and effects on sexual function are limited.

In the present study, we conducted a prospective cohort trial investigating the advantages and potential drawbacks regarding the sexual function of patients who underwent laparoscopic and abdominal hysterectomy. Our goal was to investigate whether there were any differences in the quality of sexual function postoperatively.

\section{Materials and Methods}

The present prospective cohort study was conducted in Zeynep Kamil Training and Research Hospital, which is one of the largest tertiary teaching hospitals in Turkey. All patients provided informed consent. Approval from the local ethics committee was acquired. Preoperatively, all patients underwent gynecologic examination, transvaginal ultrasounds, medical histories were obtained, and routine laboratory tests were performed.

Patients for whom hysterectomy without concurrent unilateral or bilateral adnexectomy was indicated for a benign gynecologic condition, who had a stable heterosexual relationship for at least 1 year, and who had no psychiatric disorders were included in the study. The exclusion criteria were suspicion of malignancy, a previous lower midline incision, the need for simultaneous interventions such as prolapse repair, the need for intraoperatively diagnosed adnexal pathology requiring subsequent unilateral or bilateral oophorectomy, having preoperative or postoperative hormone-therapy, and an inability to communicate in Turkish. In addition, patients with psychiatric disorders, vaginismus, lack of orgasm, a history of endometriosis, partners with sexual dysfunction, those who refused the interview, lost to follow-up, loss of sexual interest, psychological and physiological problems with partner's relationship, and in postmenopausal period were excluded from the study. The patients and their physician had decided to the route of hysterectomy. The patients were included in the study if they were scheduled for abdominal or laparoscopic hysterectomy. Patients were divided into two groups according to the surgical treatment: the total abdominal hysterectomy (TAH) group and the total laparoscopic hysterectomy (TLH) group. The demographic characteristics (age, marital status, education, and occupation) were recorded. The sexual function and quality of life were assessed 1 day preoperatively on admission to our hospital. Both of the groups' patients were contacted 6 months postoperatively and interviewed again. All questionnaires were coded with an identifying number, and women could not view their previous answers. We confirmed that all of the patients had had sexual intercourse again six months after surgery. All data were recorded and analyzed by another researcher who was blinded to the group assignments.

\section{Operating procedures}

All patients underwent general anesthesia and received preoperative antibiotic prophylaxis as well as anticoagulants during immobilization. Laparoscopic hysterectomies were all intentionally $\mathrm{TLHs}^{(8)}$ and $\mathrm{TAH}$ was performed using the standard extrafascial technique by means of clamps and suture ligation ${ }^{(9)}$. The technical aspects of both types of hysterectomy were discussed with each patient, and the appropriate hysterectomy type was selected through mutual discussion.

\section{Questionnaires}

Sexual dysfunction and quality of sexual life, psychological health status, and self-esteem were assessed preoperatively and 6 months postoperatively using standardized validated questionnaires: the Arizona Sexual Experiences Scale (ASEX), the Symptom Checklist-90-Revised (SCL-90-R), and the Rosenberg Self-Esteem Scale (RSES).

\section{Arizona Sexual Experiences Scale}

The patients'quality of sexual life was measured using the ASEX scale. The ASEX is a five-item scale with six different levels of answers that measure sexual function. The questionnaire enquires about sex drive, arousal, vaginal lubrication, ability to reach orgasm, and satisfaction with orgasm. The female and male versions of the ASEX differ on the sex-specific question 3, which addresses erection/lubrication. A total ASEX score of $\geq 19$, any one item with an individual score of 5 or 6 , and three or more items with individual scores of 4 have all been found highly correlated with physician-diagnosed sexual dysfunction(10). Patients whose partners had sexual dysfunction were eliminated from the study. We used the Turkish version of the inventory, which has been proven valid and reliable by a recent study (Cronbach's alpha $=0.91)^{(11)}$.

\section{Symptom Checklist-90-Revised Scale}

SCL-90-R was used to evaluate the psychological health status of the patients. The SCL-90-R includes items about psychosomatic symptoms of the patient and covers nine scales: 
1. Somatization;

2. Obsessive-compulsive behavior;

3. Interpersonal sensitivity;

4. Depression;

5. Anxiety;

6. Hostility;

7. Phobic anxiety;

8. Paranoid ideation;

9. Psychoticism(12,13).

Stressful personality, depression, anxiety, and somatization are generally measured using five-point scales (sores between $0-4)(14)$. Increasing scores generally indicate that the patient is anxious about the symptoms and signs. We used the Turkish version of the inventory, which has been proven valid and reliable by a recent study (Cronbach's alpha=0.83)(15).

\section{Rosenberg Self-Esteem Scale}

RSES consists of 10 items for assessing levels of self-esteem. The items are answered on a four-point scale using anchors of strongly agree (0) and strongly disagree. Its reliability and validity in Turkish were confirmed in 1986 by Çuhadaroğlu(16) and the first 10 items of the test, which assess self-esteem, were used. The subjects achieve scores between 0 and 6 according to the self-assessment system of the scale. A score of $0-1$ is considered high self-esteem, a score of 2-4 is considered moderate self-esteem, and a score of 5-6 is considered low selfesteem. A high score indicates low self-esteem, whereas a low score indicates high self-esteem.

\section{Statistical Analysis}

Statistical analysis was performed using SPSS version 21.0 for Windows. Values are expressed as mean \pm standard deviation. The Kolmogorov-Smirnov test was performed to assess the distribution of data. A comparison of two groups was performed using Student's t-test or Mann-Whitney U test for continuous variables, and the chi-square test for categorical variables. Comparisons of preoperative and postoperative scores were performed using the paired-samples t-test and Wilcoxon test. A p value of $<0.05$ was considered to indicate statistical significance.

\section{Results}

The patient flow chart is listed in detail in Figure 1. Out of 150 eligible patients, 84 completed the study. The demographic and clinical data of the two groups are summarized in Table 1.

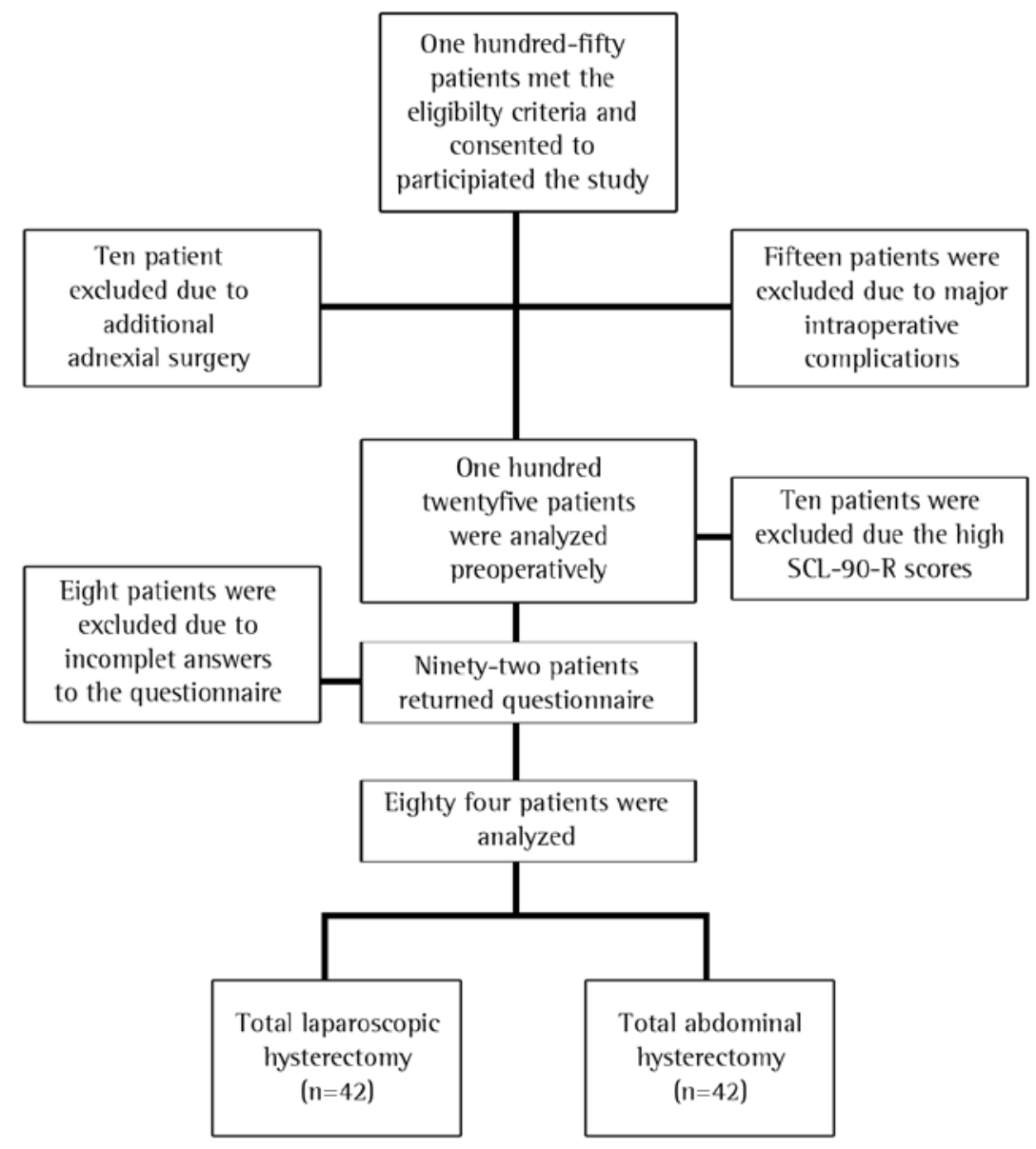

Figure 1. Flow chart of study design

SCL-90-R: Symptom Checklist-90-Revised 
Table 1. Patients' sociodemographic variables and medical characteristics prior to surgery

\begin{tabular}{|c|c|c|c|}
\hline & $\begin{array}{l}\text { Group } 1 \\
(\mathrm{TAH}) \\
\text { Mean } \pm \text { SD } \\
\%(\mathrm{n})\end{array}$ & $\begin{array}{l}\text { Group } 2 \\
(\text { TLH) } \\
\text { Mean } \pm \text { SD } \\
\%(n)\end{array}$ & $\mathrm{p}$ \\
\hline Age (year) & $42.8 \pm 2.5$ & $41.1 \pm 5.5$ & $0.161^{\mathrm{m}}$ \\
\hline BMI $\left(\mathrm{kg} / \mathrm{cm}^{2}\right)$ & $28.6 \pm 4.0$ & $29.5 \pm 6.9$ & $0.542^{\mathrm{m}}$ \\
\hline $\begin{array}{l}\text { Duration of marriage } \\
\text { (year) }\end{array}$ & $23.1 \pm 4.8$ & $24.5 \pm 9.6$ & $0.146^{\mathrm{t}}$ \\
\hline Partner age (year) & $46.8 \pm 3.6$ & $48.6 \pm 6.3$ & $0.135^{\mathrm{t}}$ \\
\hline
\end{tabular}

\section{Education status}

$\begin{array}{llll}\text { Primary school } & 41.5 \%(17) & 36.6 \%(15) & \\ \text { High school } & 36.6 \%(15) & 36.6 \%(15) & 0.850 \\ \text { University } & 22.0 \%(9) & 26.8 \%(11) & \\ \text { Occupation } & & & \\ \text { Works } & 26.8 \%(11) & 29.3 \%(12) & \\ \text { House wife } & 73.2 \%(30) & 70.7 \%(29) & 0.810 \\ \text { Gravida } & 3.4 \pm 2.0 & 4.2 \pm 2.7 & 0.146 \mathrm{~m} \\ \text { Parity } & 2.7 \pm 1.4 & 3.2 \pm 1.8 & 0.149 \mathrm{~m}\end{array}$

Route of delivery

$\begin{array}{llll}\text { Vaginal } & 75.6 \%(31) & 85.4 \%(35) & 0.850 \\ \text { Cesarean section } & 24.4 \%(10) & 17.1 \%(7) & \\ \text { Intermarriage } & & & \\ \text { Yes } & 19.5 \%(8) & 26.8 \%(11) & 0.432 \\ \text { No } & 80.5 \%(33) & 73.2 \%(30) & \\ 2^{\text {nd }} \text { degree } & 2.4 \%(1) & 0.0 \%(0) & \\ 3^{\text {rd }} \text { degree } & 12.2 \%(5) & 12.2 \%(5) & \\ 4^{\text {th }} \text { degree } & 4.9 \%(2) & 14.6 \%(6) & \end{array}$

\section{Marital status}

Single

$$
9.8 \%(4) \quad 7.3 \%(3)
$$

Married

Type of marriage

Flirting

Arranged

$90.2 \%(37)$

$92.7 \%(38)$

0.690

\section{Indication of operation}

Abnormal uterine bleeding

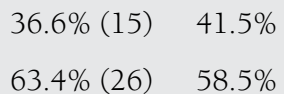

0.650

Endometrial hyperplasia

$\begin{array}{ll}36.6 \%(15) & 43.9 \%(18) \\ 17.1 \%(7) & 17.1 \%(7) \\ 26.8 \%(11) & 19.5 \%(8) \\ 19.5 \%(8) & 19.5 \%(8)\end{array}$

Myoma uteri
$19.5 \%(8)$

Cervical pathology

m:Mann-Whitney U test/t test/chi-square test, ${ }^{*} \mathrm{p}<0.05$, TLH: Total laparoscopic hysterectomy, TAH: Total abdominal hysterectomy, SD: Standard deviation
There were no statistically significant differences in the pre-and postoperative SCL-90-R scores between the groups ( $>0.05$ ) (Table 2).

Both groups exhibited a statistically significant decrease in the postoperative RSES scores compared with the preoperative scores $(\mathrm{p}<0.05)$. However, there were no statistically significant differences between the groups ( $>0.05$ ) (Table 3). Evaluations of sexual function are summarized in Table 4. No differences were observed between the two groups preoperatively. Postoperative decreases in ASEX scores (improvement in sexual function) were observed in both groups. Improvement in sex drive score and psychological arousal scores were better in the laparoscopic hysterectomy group compared with the abdominal group ( $\mathrm{p}<0.01)$.

\section{Discussion}

In the present study, decreased ASEX scores were observed 6 months postoperatively in both groups. This was more remarkable in the laparoscopy group compared with the laparotomy group. Both groups showed improvement in RSES scores; however, no significant difference was observed. Regarding the psychiatric evaluation, there were no significant differences between the groups preoperatively and 6 months postoperatively. The effects of hysterectomy on women's sexuality are controversial, and sexual function in the post-hysterectomy period is a complicated and uncertain issue by means of its results(17-21). Hysterectomy may increase the quality of life in patients who did not respond to conservative therapy by relieving symptoms(22). Nevertheless, patients preparing for hysterectomy may experience fear and anxiety of sexual function loss(23). Hysterectomy is a loss because the uterus is an organ to which women are connected psychologically. Psychosexual problems after hysterectomy are usually related to marital issues and poor body image, which are exacerbated with hysterectomy. Age, biologic and psychological factors, relationships and social and cultural circumstances affect a woman's sexuality $(2,24)$. Therefore, women's sexuality needs to be assessed through many independent factors. On the other hand, preoperative sexual function and psychological status are also important determinants of sexual dysfunction postoperatively. In our study, essential factors affecting sexuality such as self-respect and psychological status were evaluated. We observed no statistically significant changes in psychiatric scores in either group; however, amelioration of self-respect was observed postoperatively, and in our opinion, this may be a substantial factor affecting sexual improvement. In order to ensure a homogenous study population, we excluded patients with high preoperative psychiatric scores. Thus, we aimed to assess the effect of the operation on sexual life and also on the patient's psychology. Following hysterectomy, elimination of pain, discomfort, resistant menometrorrhagia associated with present disease, and risk of cancer and unwanted pregnancy may result in higher frequency of orgasms and a more satisfying sexual life(25). 
Table 2. Comparison of Symptom Checklist-90-Revised preoperative and postoperative $6^{\text {th }}$ month

$\begin{array}{lll}\text { SCL-90-R } & \begin{array}{ll}\text { Group } 1 & \text { Group 2 *p } \\ \text { (TAH) } & \text { (TLH) }\end{array}\end{array}$

\section{Somatization score}

$\begin{array}{llll}\text { Preoperative } & 1.3 \pm 1.0 & 1.4 \pm 0.9 & 0.551 \mathrm{~m} \\ \text { Postoperative } & 1.2 \pm 1.0 & 1.2 \pm 0.9 & 0.927 \mathrm{~m} \\ \text { Preop-postop difference } & 0.0 \pm 1.1 & 0.3 \pm 1.0 & 0.666 \mathrm{~m} \\ \text { Difference p } & 0.190 \mathrm{w} & 0.121 \mathrm{w} & \\ \text { Depression score } & & & \\ \text { Preoperative } & 1.0 \pm 0.8 & 1.2 \pm 1.2 & 0.410 \mathrm{~m} \\ \text { Postoperative } & 0.8 \pm 0.9 & 1.0 \pm 1.3 & 0.659 \mathrm{~m} \\ \text { Preop-postop difference } & 0.1 \pm 0.9 & 0.3 \pm 0.9 & 0.707 \mathrm{~m} \\ \text { Difference p } & 0.158 \mathrm{w} & 0.171 \mathrm{w} & \end{array}$

\section{Obsessive-compulsive behavior score}

$\begin{array}{llll}\text { Preoperative } & 1.0 \pm 0.8 & 1.2 \pm 0.8 & 0.483 \mathrm{~m} \\ \text { Postoperative } & 0.9 \pm 1.0 & 1.0 \pm 0.9 & 0.563 \mathrm{~m} \\ \text { Preop-postop difference } & 0.2 \pm 1.1 & 0.2 \pm 0.9 & 0.654 \mathrm{~m} \\ \text { Difference p } & 0.126 \mathrm{w} & 0.89 \mathrm{w} & \\ \text { Anxiety score } & & & \\ \text { Preoperative } & 0.9 \pm 0.8 & 0.9 \pm 0.7 & 0.825 \mathrm{~m} \\ \text { Postoperative } & 0.8 \pm 0.9 & 0.7 \pm 0.7 & 0.979 \mathrm{~m} \\ \text { Preop-postop difference } & 0.1 \pm 1.0 & 0.3 \pm 0.8 & 0.527 \mathrm{~m} \\ \text { Difference p } & 0.441 \mathrm{w} & 0.104 \mathrm{w} & \end{array}$

\section{Interpersonal sensitivity score}

$\begin{array}{llll}\text { Preoperative } & 1.0 \pm 0.9 & 1.1 \pm 1.0 & 0.517 \mathrm{~m} \\ \text { Postoperative } & 0.8 \pm 0.9 & 0.8 \pm 0.8 & 0.372 \mathrm{~m} \\ \text { Preop-postop difference } & 0.2 \pm 1.1 & 0.4 \pm 0.8 & 0.930 \mathrm{~m} \\ \text { Difference p } & 0.051 \mathrm{w} & 0.055^{\mathrm{w}} & \end{array}$

$\begin{array}{llll}\text { Hostility score } & & & \\ \text { Preoperative } & 0.8 \pm 0.8 & 0.7 \pm 0.6 & 0.551^{\mathrm{m}} \\ \text { Postoperative } & 0.7 \pm 0.9 & 0.7 \pm 0.8 & 0.927 \mathrm{~m} \\ \text { Preop-postop difference } & 0.0 \pm 0.9 & 0.1 \pm 0.8 & 0.666 \mathrm{~m} \\ \text { Difference p } & 0.508^{\mathrm{w}} & 0.501^{\mathrm{w}} & \end{array}$

\section{Phobic anxiety score}

$\begin{array}{llll}\text { Preoperative } & 0.5 \pm 0.6 & 0.6 \pm 0.7 & 0.947 \mathrm{~m} \\ \text { Postoperative } & 0.5 \pm 0.7 & 0.5 \pm 0.7 & 0.903 \mathrm{~m} \\ \text { Preop-Postop Difference } & 0.0 \pm 0.8 & 0.1 \pm 0.6 & 0.866 \mathrm{~m} \\ \text { Difference p } & 0.656 \mathrm{w} & 0.180 \mathrm{w} & \end{array}$

Table 2 continued. Comparison of Symptom Checklist-90-Revised preoperative and postoperative $6^{\text {th }}$ month

$\begin{array}{lll}\text { SCL-90-R } & \begin{array}{ll}\text { Group } 1 & \text { Group 2 *p } \\ \text { (TAH) } & \text { (TLH) }\end{array}\end{array}$

Paranoid ideation score

$\begin{array}{llll}\text { Preoperative } & 0.8 \pm 0.9 & 0.9 \pm 0.8 & 0.430 \mathrm{~m} \\ \text { Postoperative } & 0.6 \pm 0.8 & 0.7 \pm 0.8 & 0.515 \mathrm{~m} \\ \text { Preop-postop difference } & 0.2 \pm 1.2 & 0.4 \pm 0.8 & 0.865 \mathrm{~m} \\ \text { Difference p } & 0.090 \mathrm{w} & 0.052 \mathrm{w} & \end{array}$

\section{Psychoticism score}

$\begin{array}{llll}\text { Preoperative } & 0.6 \pm 0.6 & 0.5 \pm 0.6 & 0.637 \mathrm{~m} \\ \text { Postoperative } & 0.5 \pm 0.6 & 0.5 \pm 0.5 & 0.283 \mathrm{~m} \\ \text { Preop-postop difference } & 0.1 \pm 0.7 & 0.1 \pm 0.6 & 0.580 \mathrm{~m} \\ \text { Difference p } & 0.290 \mathrm{w} & 0.352 \mathrm{w} & \end{array}$

m:Mann-Whitney U test, w:Wilcoxon test, *p<0.05, SCL-90-R: Symptom Checklist-90Revised, TLH: Total laparoscopic hysterectomy, TAH: Total abdominal hysterectomy

Table 3. Comparison of Rosenberg Self-Esteem Scale preoperative and postoperative $6^{\text {th }}$ month

\begin{tabular}{llll} 
Rosenberg Self-Esteem Scale & $\begin{array}{l}\text { Group 1 } \\
\text { (TAH) }\end{array}$ & $\begin{array}{l}\text { Group 2 } \\
\text { (TLH) }\end{array}$ & $*$ p \\
\hline Preoperative & $2.1 \pm 1.1$ & $2.4 \pm 1.1$ & $0.147 \mathrm{~m}$ \\
\hline Postoperative & $1.1 \pm 0.8$ & $1.0 \pm 0.6$ & $0.907 \mathrm{~m}$ \\
\hline Preop-postop difference & $-1.0 \pm 1.1$ & $-1.4 \pm 1.2$ & $0.083 \mathrm{~m}$ \\
Difference p & $0.000 \mathrm{w}$ & $0.000 \mathrm{w}$ &
\end{tabular}

m: Mann-Whitney U test, w: Wilcoxon test, ${ }^{* *} \mathrm{p}<0.05$, TAH: Total abdominal hysterectomy, TLH: Total laparoscopic hysterectomy

Farrell and Kieser(26) claimed in their study that improvement in quality of life and no negative effects on sexuality were observed. The most important factor they emphasized was that there were many factors influencing sexual life and that these should be assessed in unity.

Ayoubi et al.(2) compared three types of hysterectomy (vaginal, abdominal, and laparoscopic) and found no differences in the effects on orgasm, frequency of sexual intercourse and sexual desire between groups; however, poorer body image was observed less in the TLH group compared with the TAH group. Another important finding of this study was that adverse psychological effects were observed less in the laparoscopy group. The absence of abdominal scars in the laparoscopy group and less postoperative pain may explain these findings.

A study that compared 5 different hysterectomy procedures conducted by Lermann et al.(27) reported that women in the laparoscopic supracervical hysterectomy (LASH) and TLH groups had more favorable results. However, the difference between TLH and LASH groups was not statistically significant. 
The study of Lermann et al.(27) was a long-term and broad study but the retrospective study design and lack of sexual evaluation before surgery were important limitations of the study. Although statistical significant differences between the groups were not encountered, the conclusion of less invasive methods had more favorableresults was compatible with our results.

Table 4. Comparison of Arizona Sexual Experiences Scale score preoperative and postoperative

$\begin{array}{lll}\text { Female Arizona Sexual } & \text { Group } 1 & \text { Group } 2+p \\ \text { Experiences Scale } & \text { (TAH) } & \text { (TLH) }\end{array}$

\section{Sexual drive}

\begin{tabular}{|c|c|c|c|}
\hline Preoperative & $3.3 \pm 1.2$ & $3.6 \pm 1.2$ & $0.185^{\mathrm{m}}$ \\
\hline Postoperative & $2.7 \pm 1.0$ & $1.7 \pm 0.8$ & $<0.001^{\mathrm{m}}$ \\
\hline Preop-postop difference & $0.7 \pm 1.1$ & $1.9 \pm 1.4$ & $<0.001^{\mathrm{m}}$ \\
\hline Difference $\mathrm{p}$ & $0.000 \mathrm{w}$ & $0.001^{w}$ & \\
\hline \multicolumn{4}{|l|}{ Arousal } \\
\hline Preoperative & $3.4 \pm 1.3$ & $3.8 \pm 0.9$ & $0.138^{m}$ \\
\hline Postoperative & $2.7 \pm 1.1$ & $2.0 \pm 0.8$ & $0.002^{\mathrm{m}}$ \\
\hline Preop-postop difference & $0.7 \pm 1.1$ & $1.8 \pm 1.2$ & $<0.001^{m}$ \\
\hline Difference $\mathrm{p}$ & $0.000 \mathrm{w}$ & $0.001^{w}$ & \\
\hline \multicolumn{4}{|l|}{ Vaginal lubrication } \\
\hline Preoperative & $3.1 \pm 1.0$ & $3.4 \pm 0.8$ & $0.180^{\mathrm{m}}$ \\
\hline Postoperative & $2.5 \pm 0.8$ & $2.3 \pm 0.9$ & $0.258^{\mathrm{m}}$ \\
\hline Preop-postop difference & $0.1 \pm 1.0$ & $1.0 \pm 1.1$ & $0.051 \mathrm{~m}$ \\
\hline Difference $\mathrm{p}$ & $0.000^{w}$ & $0.002 \mathrm{w}$ & \\
\hline \multicolumn{4}{|l|}{ Ability to reach orgasm } \\
\hline Preoperative & $3.4 \pm 1.1$ & $3.4 \pm 1.2$ & $0.796^{m}$ \\
\hline Postoperative & $2.7 \pm 1.1$ & $2.8 \pm 1.1$ & $0.846 \mathrm{~m}$ \\
\hline Preop-postop difference & $0.8 \pm 1.5$ & $0.7 \pm 1.2$ & $0.895^{\mathrm{m}}$ \\
\hline Difference $\mathrm{p}$ & $0.002 w$ & $0.0091^{w}$ & \\
\hline
\end{tabular}

\section{Satisfaction with orgasm score}

$\begin{array}{llll}\text { Preoperative } & 2.9 \pm 1.2 & 3.0 \pm 1.2 & 0.679 \mathrm{~m} \\ \text { Postoperative } & 2.4 \pm 1.2 & 2.0 \pm 1.0 & 0.105 \mathrm{~m} \\ \text { Preop-postop difference } & 0.6 \pm 1.1 & 1.0 \pm 1.4 & 0.064 \mathrm{~m} \\ \text { Difference p } & 0.000 \mathrm{w} & 0.004 \mathrm{w} & \\ \text { Total score } & & & \\ \text { Preoperative } & 16.1 \pm 4.3 & 17.2 \pm 3.7 & 0.135 \mathrm{~m} \\ \text { Postoperative } & 12.9 \pm 3.7 & 10.8 \pm 2.1 & 0.008 \mathrm{~m} \\ \text { Preop-postop difference } & 3.2 \pm 3.9 & 6.4 \pm 3.3 & <0.001 \mathrm{~m} \\ \text { Difference p } & 0.000 \mathrm{w} & 0.000 \mathrm{w} & \end{array}$

m: Mann-Whitney U test, w: Wilcoxon test, + p<0.05, TAH: Total abdominal hysterectomy, TLH: Total laparoscopic hysterectomy
Gutl et al.(28) compared vaginal hysterectomy (VH) and TAH groups. The authors assessed patients 3 months and 2 years postoperatively and observed improvement on sexual function in both groups; more pain and poor self-image were observed in the TAH group, which may be associated with abdominal scar appearance. In addition, the recovery period was longer compared with the VH group. Hehenkamp et al.(29) randomly assigned patients to undergo uterine artery embolization and hysterectomy for the treatment uterine fibroids, then assessed sexual activity and body image scales in both groups. Improvement was more apparent in the uterine artery embolization group. Less invasive methods of surgery appear to have a positive impact on quality of life and patient comfort. This favorable change in self-body image and quality of life also has indirect positive repercussions on sexual life. Both TLH and TAH groups showed decreased postoperative ASEX scores. In comparison with abdominal operations, sexual drive scores and arousal scores decreased more in the TLH group, which indicated improvement in sexual function. TLH appears to have advantages for women who require total hysterectomy for benign indications, particularly with regard to sexual functions. The main strengths of our study were the prospective observational design and the patients were chosen homogeneously. However, the small number of the study group and short follow-up period ( 6 months postoperatively) were the main limitations of the study.

\section{Conclusion}

In conclusion, laparoscopic surgery should be performed on suitable patients considering that it is less invasive, has a shorter recovery period, and has positive effects on sexual function and quality of life. We think that further research with a prospective long-term follow-up design is necessary to identify a surgical option associated with maximum preservation of sexual function during hysterectomy procedures.

\section{Ethics}

Ethics Committee Approval: All procedures performed in studies involving human participants were in accordance with the ethical standards of the institutional and/or national research committee and with the 1964 Helsinki declaration and its later amendments or comparable ethical standards. Approval number: 127/2013, Informed Consent: Informed consent was obtained from all individual participants included in the study. Peer-review: Internally peer-reviewed.

\section{Authorship Contributions}

Surgical and Medical Practices: Meryem Kürek Eken, Ateş Karateke, Concept: Meryem Kürek Eken, Gülşah İlhan, Evrim Erbek Çelik, Design: Ateş Karateke, Meryem Kürek Eken, Evrim Erbek Çelik, Data Collection or Processing: Meryem Kürek Eken, Dilşad Herkiloğlu, Evrim Erbek Çelik, Analysis or Interpretation: Meryem Kürek Eken, Gülşah İlhan, Osman Temizkan, Literature Search: Osman Temizkan, Evrim Erbek 
Çelik, Dilşad Herkiloğlu, Writing: Meryem Kürek Eken, Gülşah İlhan, Osman Temizkan.

Conflict of Interest: No conflict of interest was declared by the authors.

Financial Disclosure: The authors declared that this study received no financial support.

\section{References}

1. Wallwiener M, Taran FA, Rothmund R, Kasperkowiak A, Auwarter G, Ganz A, et al. Laparoscopic supracervical hysterectomy (LSH) versus total laparoscopic hysterectomy (TLH): an implementation study in 1,952 patients with an analysis of risk factors for conversion to laparotomy and complications, and of procedure-specific reoperations. Arch Gynecol Obstet 2013;288:1329-39.

2. Ayoubi JM, Fanchin R, Monrozies X, Imbert P, Reme JM, Pons JC. Respective consequences of abdominal, vaginal, and laparoscopic hysterectomies on women's sexuality. Eur J Obstet Gynecol Reprod Biol 2003;111:179-82.

3. Farquhar CM, Steiner CA. Hysterectomy rates in the United States 1990-1997. Obstet Gynecol 2002;99:229-34.

4. Altman D, Granath F, Cnattingius S, Falconer C. Hysterectomy and risk of stress-urinary-incontinence surgery: nationwide cohort study. Lancet 2007;370:1494-9.

5. Pauls RN. Impact of gynecological surgery on female sexual function. Int J Impot Res 2010;22:105-14.

6. Takeda A, Imoto S, Mori M, Yamada J, Nakamura H. Management of large adnexal tumors by isobaric laparoendoscopic single-site surgery with a wound retractor. Eur J Obstet Gynecol Reprod Biol 2013;166:185-9.

7. Nieboer TE, Johnson N, Lethaby A, Tavender E, Curr E, Garry R, et al. Surgical approach to hysterectomy for benign gynaecological disease. Cochrane Database Syst Rev 2009:CD003677.

8. Thiel F, Renner S, Oppelt P, al. e. Establishment of total laparoscopic hysterectomy (TLH) in a university gynecology department: Results of the first 100 operations. Geburtshilfe und Frauenheilkunde 2006;66:665-9.

9. Mueller A, Boosz A, Koch M, Jud S, Faschingbauer F, Schrauder $\mathrm{M}$, et al. The Hohl instrument for optimizing total laparoscopic hysterectomy: results of more than 500 procedures in a university training center. Arch Gynecol Obstet 2012;285:1237.

10. McGahuey CA, Delgado LP, Geleberg AJ. Assessment of sexual dysfunction using the Arizona Sexual Experience Scale (ASEX) and implications for the treatment of depression. Psychiatric Ann 1999;29:39-45.

11. Soykan A. The reliability and validity of Arizona sexual experiences scale in Turkish ESRD patients undergoing hemodialysis. Int J Impot Res 2004;16:531-4.
12. Cunha I, Brissos S, Dinis M, Mendes I, Nobre A, Passao V. Comparison between the results of the Symptom Check List- 90-R of two different populations with temporal lobe epilepsy. Epilepsy Behav 2003;4:733-9.

13. Numan N. Exploration of adverse psychological symptoms in Yemeni khat users by the Symptoms Checklist-90 (SCL-90). Addiction 2004:99:61-5.

14. Reisch T, Vijayananda S, Gekle W, Tschacher W. [A Qualitative Follow-Up Assessment two Years after Inpatient Crisis Intervention]. Psychiatr Prax 2004;31:16-22.

15. Kılınç M. Belirti Tarama Listesi (SCL-90-R) nin Geçerlilik ve Güvenirliği. Psikolojik Danışma ve Rehberlik Dergisi 1991;1:45-52.

16. Çuhadaroğlu F. Adolesanlarda benlik saygısı. Yayınlanmamış Uzmanlık Tezi, Psikiyatri Anabilim D, Ankara, 1986.

17. Morokoff PJ, Gillilland R. Stress, sexual functioning, and marital satisfaction. J Sex Res 1993;30:43-53.

18. Richards DH. A post-hysterectomy syndrome. Lancet 1974;2:983-5.

19. Kaltreider NB, Wallace A, Horowitz MJ. A field study of the stress response syndrome. Young women after hysterectomy. JAMA 1979;242:1499-503.

20. Roovers JP, van der Bom JG, van der Vaart CH, Heintz AP. Hysterectomy and sexual wellbeing: prospective observational study of vaginal hysterectomy, subtotal abdominal hysterectomy, and total abdominal hysterectomy. BMJ 2003;327:774-8.

21. Helstrom L. Sexuality after hysterectomy: a model based on quantitative and qualitative analysis of 104 women before and after subtotal hysterectomy. J Psychosom Obstet Gynaecol 1994;15:219-29.

22. Wattiez A, Cohen SB, Selvaggi L. Laparoscopic hysterectomy. Curr Opin Obstet Gynecol 2002;14:417-22.

23. Mokate T, Wright C, Mander T. Hysterectomy and sexual function. J Br Menopause Soc 2006;12:153-7.

24. Lamont J, Society of O, Gynaecologists of C. Female sexual health consensus clinical guidelines. J Obstet Gynaecol Can 2012;34:769-83.

25. Huffman JW. Sex after hysterectomy. . Med Aspects Human Sexuality 1985;19:171-9.

26. Farrell SA, Kieser K. Sexuality after hysterectomy. Obstet Gynecol 2000;95:1045-51.

27. Lermann J, Haberle L, Merk S, Henglein K, Beckmann MW, Mueller A, et al. Comparison of prevalence of hypoactive sexual desire disorder (HSDD) in women after five different hysterectomy procedures. Eur J Obstet Gynecol Reprod Biol 2013;167:210-4.

28. Gutl P, Greimel ER, Roth R, Winter R. Women's sexual behavior, body image and satisfaction with surgical outcomes after hysterectomy: a comparison of vaginal and abdominal surgery. J Psychosom Obstet Gynaecol 2002;23:51-9.

29. Hehenkamp WJ, Volkers NA, Bartholomeus W, de Blok S, Birnie E, Reekers JA, et al. Sexuality and body image after uterine artery embolization and hysterectomy in the treatment of uterine fibroids: a randomized comparison. Cardiovasc Intervent Radiol 2007;30:866-75. 